\title{
Chemical treatment of post-harvest Marandu grass seed residues with different moisture contents ${ }^{1}$
}

\author{
Marcella de Toledo Piza Roth², Ricardo Andrade Reis ${ }^{3,4}$, Flávio Dutra de Resende ${ }^{3,5}$, \\ Gustavo Rezende Siqueira ${ }^{5}$, Aureliano José Vieira Pires ${ }^{6}$, Liandra Maria Abaker Bertipaglia ${ }^{7}$ \\ 1 Projeto financiado pela FAPESP. \\ 2 UNIFEB - Centro Universitário da Fundação Educacional de Barretos. Av. Rui Barbosa, s/n, CP.35, Cep: 14770-000 Colina, SP. \\ ${ }^{3}$ Departamento de Zootecnia da Unesp/Campus de Jaboticabal. \\ 4 Pesquisador do CNPq, Membro do INCT/CA. \\ ${ }^{5}$ Apta - Pólo Regional do Desenvolvimento dos Agronegócios da Alta Mogiana - Colina, SP. \\ ${ }^{6}$ DTRA/UESB - Campus de Itapetinga. \\ 7 UNICASTELO - Universidade Camilo Castelo Branco. Av. Hilário da Silva Passos, 950, Cep: 13690-000, Descalvado, SP.
}

ABSTRACT - The objective of this was to evaluate the effect of chemical treatments with urea (3 or 5\% DM) and anhydrous ammonia (3\% DM) applied to the post-harvest hay residues of Brachiaria brizantha cv. Marandu that contained different moisture contents (15, 25 or 30\%). A randomized block design was used with eight treatments and four replications (defined as the bale layers within the hay stacks). The hay treated with 3\% anhydrous ammonia and 15\% moisture content reduced the levels of neutral detergent fiber (NDF) from 84.3 to $79.1 \%$ and increased the in vitro digestibility of the dry matter (DM) from 37.3 to $55.5 \%$ compared to the control group. The variation in the moisture content did not significantly alter the action of ammonia, with mean values of $77.6 \% \mathrm{NDF}$ and $57.3 \%$ in vitro digestibility of DM. The hay with $5 \%$ urea reduces the NDF content from 84.3 to $79.6 \%$ compared to the untreated hay, so the hay moisture content has to be increased to $30 \%$ to achieve a greater effect on the DM digestibility, which subsequently increases by 12 percentage units.

Key Words: ammonia, carbohydrate fractionation, nitrogen fractionation, nutritional value, urea

\section{Tratamento químico do resíduo pós-colheita de sementes de capim- marandu com diferentes teores de umidade}

\footnotetext{
RESUMO - Objetivou-se avaliar o efeito do tratamento químico com ureia (3 ou 5\% na MS) e amônia anidra (3\% na MS) no feno de resíduo pós-colheita de sementes de Brachiaria brizantha, cv. Marandu, contendo diferentes teores de umidade (15, 25 ou 30\%). O delineamento experimental foi em blocos ao acaso com oito tratamentos e quatro repetições (camadas de fardos dentro das pilhas). O feno tratado com 3\% de amônia anidra com 15\% de umidade ocasionou redução de 84,3 para 79,1\% nos teores de fibra em detergente neutro (FDN) e elevação de 37,3 para 55,5\% na digestibilidade in vitro da matéria seca (MS) em relação ao grupo controle. A variação na umidade não alterou de maneira significativa a ação da amônia, cujos valores médios foram $77,6 \%$ de FDN e 57,3\% de digestibilidade in vitro da MS. O feno com 5\% de ureia reduziu os teores de FDN de 84,3 para $79,6 \%$ em relação ao feno não-tratado, o que tornou necessário o aumento da umidade para 30\% para maior efeito sobre a digestibilidade da MS, que aumentou 12 unidades percentuais.
}

Palavras-chave: amônia, fracionamento de carboidratos, fracionamento de nitrogênio, ureia, valor nutritivo

\section{Introduction}

An alternative feeding regime that can be used to avoid fluctuations in meat and milk supply throughout the year is the feeding of available low cost food to ruminants during the dry season. The provision of low cost food could be achieved through the efficient use of fibrous materials as supplements to the feed, such as the residual straw from seed grass production. This residue is available specifically in the dry season and amounts to about 2.8 million t per year (Souza \& Silveira, 2006). Currently most of the residue is burned, generating a significant environmental impact. The roughages that result from straw residue are usually of low quality because they have a high cell wall content (values above 60\%), high acid detergent fiber content (above 40\%), low crude protein contents (below 6\%) and low dry matter digestibility (approximately $40 \%$ ), which results in low intake levels (Reis \& Rodrigues, 1993). 
In order to improve the nutritional value of these roughages, treatments with oxidants or hydrolytic compounds, such as anhydrous ammonia $\left(\mathrm{NH}_{3}\right)$ and urea as a source of ammonia, can be used. Despite the lower cost and ease of acquisition of these chemical products, the use of urea as a source of ammonia has an efficiency limitation in terms of the amount of water wasted in the application process, which complicates its practical application (Reis et al. 2001).

The application of urea as a source of ammonia for forage treatment has advantages over treatments with anhydrous ammonia in terms of availability, lower cost and easy use. However, it has as a major limitation in the difficulty in transforming it into ammonia (Sahnoume et al., 1991).

Several studies on the treatment of feed roughages with urea, such as the study by Pires et al. (2006), have indicated the importance of forage moisture content in the hydrolysis process. According to the review by Freitas et al. (2002), the forage moisture content can be the main determinant of urea hydrolysis.

The objective of this study was to evaluate the effect of applying urea or anhydrous ammonia on the nutritive value of post-harvest hay residue from Brachiaria brizantha $\mathrm{cv}$. Marandu with different moisture contents.

\section{Materials and Methods}

The experiment was carried out in the forage crop and pasture section of Jaboticabal FCAV/UNESP, Jaboticabal, São Paulo. The site is located at $21^{\circ} 15^{\prime} 22^{\prime \prime} \mathrm{S}$ and $48^{\circ} 18^{\prime} 58^{\prime \prime} \mathrm{W}$ and is $595 \mathrm{~m}$ above sea level.

According to the international Koppen classification, the climate is mesothermal, with dry winters, an annual average maximum temperature of $22.3^{\circ} \mathrm{C}$ and an annual minimum temperature of $15.2^{\circ} \mathrm{C}$. The rainfall average is $1,400 \mathrm{~mm}$, with $85 \%$ of the rainfall concentrated from October to March.

The roughage used to create the hay used in this study originated from the Brachiaria brizantha $\mathrm{cv}$. Marandu plant. The hay was produced using the remaining forage crop residues collected by the scanning method. The treatments in this study were combinations of urea $(0,3$ or $5 \%$ ) or ammonia ( 0 or $3 \%$ of the DM) that were applied at different hay moisture contents (15, 25, or $30 \%)$.

According to the data presented by Sundstol \& Coxworth (1984), Sahnoune et al. (1991) and Joy et al. (1992), the resultant roughage shows adequate characteristics for urease activity when the water content ranges from 25 to $30 \%$. At lower moisture contents, the applied urea reaction is not sufficient to alter the forage chemical composition and digestibility.

The chemical treatment was applied to the hay bales that weighed 7 to $8 \mathrm{~kg}$ each. The bales were arranged in layers and each stack consisted of four layers of bales that were placed on plastic sheeting, totaling a DM weight of $300 \mathrm{~kg}$. An additional plastic tarp was used to cover the stacks, so that they were stored in airtight conditions during the treatment period that lasted 30 days.

Urea $\left(\mathrm{CH}_{4} \mathrm{~N}_{2} \mathrm{O}\right)$ was applied to the bales using a spray containing a concentration representing either 3.0 or $5.0 \%$ of the dry weight of the bale stacks. The urea was diluted with water to obtain the final roughage moisture content of 25 and $30 \%$. The urea solution was distributed across the hay bales by watering the layers as the stack was being formed on top of the polyethylene tarp, following the recommendations of Dolberg (1991) and Joy et al. (1992).

The anhydrous ammonia $\left(\mathrm{NH}_{3}\right)$ was then injected into the bales in each stack, in a quantity equal to $3.0 \%$ of the dry weight, as recommended by Sundstol \& Coxworth (1984).

The moisture content was adjusted by adding water, which was sprayed from a watering can in the amount calculated to raise the moisture content from $15 \%$ to 25 or $30 \%$. The quantity of water was determined by considering the total weight of the stack and the DM content of the hay bales. The weight of the stack (DM) was divided by the desired DM content and then multiplied by the original dry matter to obtain the weight of the stacks after adding the water.

Stacks of untreated roughage were also produced and these control stacks remained under the same storage conditions as the urea and $\mathrm{NH}_{3}$ treated roughage for the duration of the study.

The temperature of the stacks was measured daily over the 30 days of storage under the hermetically sealed conditions using a $50 \mathrm{~cm}$ Digital Electronic Stem Thermometer.

After the 30 day period, the bale stacks were opened and remained uncovered and in aeration for three days to remove the excess $\mathrm{NH}_{3}$ that did not react with the roughage. To determine the chemical constituents of the samples, two aliquots were collected from each hay bale that were then homogenized, resulting in one compound sample from each layer within each of the stacks. The collected samples were frozen and ground to avoid ammonia nitrogen loss during the following drying process in an oven.

The chemical analysis of the roughage sample was conducted in the Forage Crop Laboratory of FCAV/ Unesp, on the Jaboticabal Campus. The methods of Silva \& Queiroz (2002) were used to determine the contents of the dry matter (DM), crude protein (CP), neutral detergent 
insoluble nitrogen (NDIN), acid detergent insoluble nitrogen (ADIN), neutral detergent fiber (NDF), acid detergent fiber (ADF) and lignin content. The hemicellulose (HEM) and cellulose (CEL) contents were calculated by taking the difference between the NDF and the ADF and the difference between the ADF and the lignin, respectively. The ammonia nitrogen contents (NH3-N) were determined according to the methodology by Fenner (1965), modified by Vieira (1980). The nitrogen fractioning was completed as described by the Cornell Net Carbohydrate and Protein System (CNCPS); in the following manner: fractions A, B1, B2, B3 and C were analyzed according to the methodology described by Licitra et al. (1996). To obtain the carbohydrate fractions, according to the CNCPS system, the contents of total nitrogen of the samples (NT), ether extracts and ash were determined (AOAC, 1990). The total carbohydrates were determined using the expression $\mathrm{CT}=$ 100 - (\% CP +\% EE +\% MM) (Sniffen et al., 1992) and the non-structural carbohydrates (A + B1), using the following expression: $\mathrm{CNE}=100-(\% \mathrm{CP}+\% \mathrm{EE}+\% \mathrm{FDNCP}+\mathrm{MM})$, in which the FDNCP represented the cell wall corrected for the ash and the protein. The $\mathrm{C}$ fraction was obtained using the indigestible residue that remained after 144 hours incubation with rumen fluid (Berchielli et al., 2000). The B2 fraction was analyzed as the difference between 100 and the NDF remaining after 144 hours of incubation. The dry matter (DM) in vitro digestibility was evaluated using the Tilley \& Terry method that is reported by Silva \& Queiroz (2002).
The data were analyzed in a randomized block design with 8 treatments and 4 replications (the bale layers within the stacks), using the SAS statistical program (1999).

\section{Results and Discussion}

The alterations in the daily temperature of the observed bale stacks reflected the variations in the environmental temperature and were probably not affected by microorganism activity in the hay (Figure 1). In general, the ammoniation did not increase the temperature.

The untreated hay had the lowest $\mathrm{pH}$ values (Table 1) and did not differ from the hay that was treated with 3\% urea at 30\% moisture, or those treated with 5\% urea. The highest values were observed in the hay bales treated with anhydrous ammonia, regardless of the moisture content, as well as those treated with urea that had a $25 \%$ moisture content. These hay samples, however, did not differ from the others treated with urea.

According to Berger et al. (1994), this rise in $\mathrm{pH}$ is caused by the formation of a weak base, ammonium hydroxide $\left(\mathrm{NH}_{4} \mathrm{OH}\right)$, due to the affinity of $\mathrm{NH}_{3}$ for the water contained in the forage. The increase in the forage $\mathrm{pH}$ should be sufficient to allow the breaking of the ester type bonds between the lignin and the structural carbohydrates (Mascarenhas-Ferreira et al., 1989). $\mathrm{NH}_{4} \mathrm{OH}$ formation is important in the ammoniation process, as it increases the efficiency of this process through alkaline hydrolysis (Sundstol \& Coxworth, 1984).

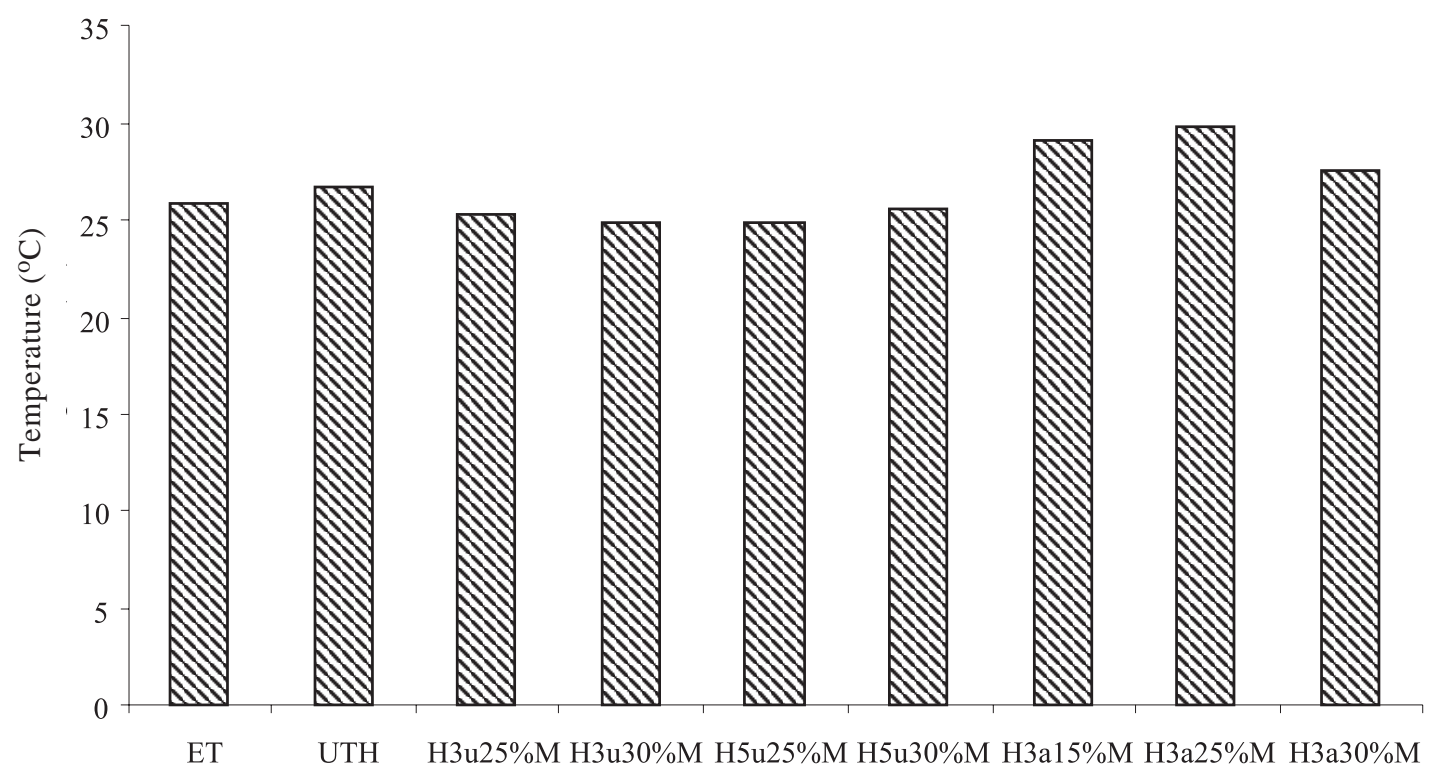

ET: environmental temperature; UTH: untreated hay; H3u: hay treated with 3\% urea DM with 25\% or 30\% moisture (M); H5u: hay treated with 5\% urea DM with 25\% or $30 \%$ moisture; H3a: hay treated with $3 \%$ ammonia DM with 15 , 25 or $30 \%$ moisture (M).

Figure 1 - Average temperatures $\left({ }^{\circ} \mathrm{C}\right)$ of the environment and the Brachiaria brizantha hay treated with urea or anhydrous ammonia $\left(\mathrm{NH}_{3}\right)$ and different moisture contents. 
Table 1 - pH values and nitrogen fractions of Brachiaria brizantha cv. Marandu hay treated with urea or anhydrous ammonia $\left(\mathrm{NH}_{3}\right)$ and different moisture contents

\begin{tabular}{|c|c|c|c|c|c|}
\hline \multirow[t]{2}{*}{ Item } & \multirow[t]{2}{*}{$\mathrm{pH}$} & $\mathrm{CP}^{1}$ & $\mathrm{~N}-\mathrm{NH}_{3}$ & $\mathrm{ADIN}^{2}$ & $\mathrm{NDIN}^{3}$ \\
\hline & & \multicolumn{4}{|c|}{$\% \mathrm{DM}$} \\
\hline Non-treated hay with $15 \%$ moisture & $7.28 b$ & $3.32 \mathrm{~d}$ & $0.02 \mathrm{e}$ & $0.14 \mathrm{e}$ & $0.29 \mathrm{~d}$ \\
\hline Hay 25\% moisture with $3 \%$ urea & $7.61 \mathrm{a}$ & $7.33 \mathrm{~cd}$ & $0.32 d$ & $0.20 \mathrm{bcd}$ & $0.32 \mathrm{bcd}$ \\
\hline Hay $30 \%$ moisture with $3 \%$ urea & 7.49ab & $7.02 \mathrm{~cd}$ & $0.43 \mathrm{~cd}$ & $0.19 \mathrm{~cd}$ & $0.31 \mathrm{~cd}$ \\
\hline Hay $25 \%$ moisture with $5 \%$ urea & $7.43 \mathrm{ab}$ & $10.75 b c$ & $0.31 \mathrm{~d}$ & 0.17 de & $0.30 \mathrm{~cd}$ \\
\hline Hay $30 \%$ moisture with $5 \%$ urea & $7.43 \mathrm{ab}$ & $17.22 \mathrm{a}$ & $0.58 b$ & $0.23 \mathrm{bc}$ & $0.34 \mathrm{abc}$ \\
\hline Hay $15 \%$ moisture with $3 \%$ ammonia & $7.68 \mathrm{a}$ & $12.09 b$ & $0.52 b c$ & $0.24 b$ & $0.30 \mathrm{~cd}$ \\
\hline Hay $25 \%$ moisture with $3 \%$ ammonia & $7.58 \mathrm{a}$ & $13.71 \mathrm{ab}$ & $0.73 a$ & $0.30 \mathrm{a}$ & $0.35 \mathrm{ab}$ \\
\hline Hay $30 \%$ moisture with $3 \%$ ammonia & $7.57 \mathrm{a}$ & $14.81 \mathrm{ab}$ & $0.74 \mathrm{a}$ & $0.34 \mathrm{a}$ & $0.37 \mathrm{a}$ \\
\hline Average & 7.51 & 10.78 & 0.46 & 0.3 & 0.32 \\
\hline CV (\%) & 1.5 & 16.0 & 11.8 & 8.9 & 5.1 \\
\hline
\end{tabular}

Averages followed by different letters in the columns differ $(\mathrm{P}<0.05)$ by Tukey test.

${ }^{1} \mathrm{CP}$ : crude protein; $\mathrm{N}-\mathrm{NH}_{3}$ : ammonia nitrogen, ADIN: acid detergent insoluble nitrogen; and NDIN: neutral detergent insoluble nitrogen expressed in \% DM.

${ }^{2}$ ADIN values in percentage of total nitrogen: $25.8 \%, 17.2 \%, 17.4 \%, 10.3 \%, 8.4 \%, 12.6 \%, 13.7 \%, 14.0 \%$, respectively, by the order of treatments presented in the table.

${ }^{3}$ NDIN values in percentage of total nitrogen: $54.6 \%, 27.6 \%, 27.8 \%, 18.9 \%, 12.4 \%, 15.6 \%, 16.1 \%, 15.6 \%$, respectively, by the order of treatments presented in the table.

The untreated hay had a lower crude protein content (3.32\%), regardless of the moisture content, but this difference was not significant for the hay treated with $3 \%$ urea (Table 1). The other hay samples (those with 5\% urea and 3\% ammonia) showed an increase from 7.43 to 13.9 percentage points in the crude protein content (CP) as compared to the control, regardless of moisture content. The treatment with 5\% urea at 30\% moisture that resulted in the highest CP value (17.22\%); however, it did not differ from the treatment with $3 \%$ ammonia at 25 or $30 \%$ moisture. These data are consistent with those reported by Reis et al. (1991), who evaluated the effect of ammoniation with anhydrous ammonia and obtained increases of 7.13, 8.5 and 10.5 percentage units of CP in the hay derived from Brachiaria brizantha cv. Marandu treated with 2, 4 and 6\% anhydrous ammonia. Nevertheless, the values observed in this study were higher than those determined by Fernandes et al. (2002), who obtained 9.7 and $12.2 \%$ CP in hay treated with $3 \%$ anhydrous ammonia and 5\% urea, respectively.

The ammonia nitrogen contents (NH3-N) increased in the treated hay compared to the hay without an added nitrogen source (Table 1). The greatest NH3-N contents were observed in the hay treated with ammonia and stored at 25 and $30 \%$ moisture ( 0.73 and $0.74 \%$, respectively). In the hay treated with urea, the increase was lower than in that treated with anhydrous ammonia. These differences may be related to the dependence on urease action for the conversion of urea to ammonia, since $\mathrm{N}-\mathrm{NH}_{3}$ is a result of this reaction. In the presence of the urease enzyme, urea is converted into ammonia, which, on contact with water, turns into ammonium hydroxide - a substance with 29 to $30 \%$ ammonia $\left(\mathrm{NH}_{3}\right)$. Consequently, the hay treated directly with ammonia has a higher $\mathrm{N}-\mathrm{NH}_{3}$ concentration (Sundstol \& Coxworth, 1984).
The acid detergent insoluble nitrogen (ADIN) contents were affected in the majority of the hay samples (Table 1 ). The lowest ADIN value (0.14\%) was obtained in the hay with no addition of chemical products, and there was no significant difference in hay treated with 5\% urea and 25\% moisture. The greatest values were observed in the hay treated with $3 \%$ ammonia and 25 and $30 \%$ moisture. Increase in the ADIN contents in the treated hay, according to Buettner et al. (1982), may be due to the ammonolysis reaction, since the dosed nitrogen was retained in the acid detergent insoluble portion of the hay (cellulose and lignin).

The ammonolysis reaction can be defined as the principal reaction between ammonia and the ester linkages of the forage fibrous fraction that are found in the hemicellulose chains and structural carbohydrates groups or between molecules of structural carbohydrates and lignin. The result is the formation of amides (Reis \& Rodrigues, 1993).

The hay treated with $3 \%$ ammonia at 30\% moisture showed the highest amount of neutral detergent insoluble (NDIN) (0.37\%) but it did not differ from the hay treated with $3 \%$ ammonia and $25 \%$ moisture $(0.35 \%)$ or $5 \%$ urea and $30 \%$ moisture $(0.34 \%)$. The control hay and the other materials showed lower values of this fraction.

According to Fernandes et al. (2002), both the values for the acid detergent insoluble nitrogen (ADIN) and neutral detergent insoluble nitrogen (NDIN) tend to increase with the addition of ammonia or urea. This response would be harmful to animals, as these fractions are not degraded or are very slowly degraded in the rumen. However, Fernandes et al. (2002) did not find a significant difference between the treatments in their experiment. The observed ADIN and NDIN values in the untreated Brachiaria decumbens hay in the present study were similar to those found by these authors, $0.28 \%$ and $0.34 \%$, 
respectively. Fernandes et al. (2002) also observed ADIN and NDIN concentrations of $0.33 \%$ and $0.45 \%$ in Brachiaria decumbens hay treated with 3\% anhydrous ammonia and $0.29 \%$ and $0.39 \%$ in Brachiaria decumbens hay treated with 5\% urea. These results were close to those obtained in the present study.

Nitrogen fractionation (Table 2) may more precisely characterize the components of a feed based on the protein content according to solubility and rumen degradation. Sniffen et al. (1992) suggested that nitrogen compounds were subfractionated in fractions A (soluble fraction, consisting of non-protein nitrogen - NPN), B1 (fraction rapidly degraded in the rumen), B2 (insoluble fraction, with an intermediate rate of degradation in the rumen), B3 (insoluble fraction slowly degraded in the rumen) and $\mathrm{C}$ (insoluble fraction in the rumen and indigestible in the gastrointestinal tract).

The contents of fraction A of total nitrogen, which represents the fraction of this nutrient that is found in the non-protein nitrogen form (Table 2), were high in all the treatments with the added nitrogen (urea or ammonia) compared to the control hay. According to Berger et al. (1994), the main form of nitrogen retention, via urea, in the process of ammoniation is the non-protein nitrogen, which is the soluble $\mathrm{N}$ fraction of the forage. The greatest value was found in treatments with 5\% urea and 30\% moisture (77.1\%), but this change was not statistically different from treatments with 5\% urea and 25\% moisture (73.5\%) and 3\% ammonia and 30\% moisture (73.6\%). This response can be explained by the amount of additional nitrogen and moisture, because the greatest values were observed in these treatments, suggesting that the presence of greater moisture with a greater content of added non-protein nitrogen created conditions that were more conducive to the fixation of this fraction in the treated material. On the other hand, the treatments with lower added contents and lower moisture showed statistically lower values of the fraction A in their make-up.

The fraction B1 (Table 2) contents decreased in the treated hay $(\mathrm{P}<0.05)$ compared to the control, and between the treated hay there were no detected differences $(\mathrm{P}>0.05)$.

Fraction B2 had greater values in the control hay when compared to the other hays; however, these varied and the lowest value of this fraction was in the hay with $5 \%$ urea and $30 \%$ moisture (6.2\%) compared to the hay with $3 \%$ urea and $30 \%$ moisture (14.3\%).

It is noteworthy that the reduction in fractions B1 and B2 can be derived from the proportional effect of nitrogen inclusion, which appears in the form of non-protein nitrogen (fraction A), because these fractions represent the portion of true protein that is little affected by including external nitrogen sources in the form of urea or ammonia, as these sources are formed from non-protein nitrogen.

Fraction B3 (Table 2) was affected by urea addition regardless of the moisture. This effect was less marked in the hay that was treated with $\mathrm{NH}_{3}$, with no significant difference $(\mathrm{P}>0.05)$. Normally, fraction B3 is reduced by urea application or ammonia, as these solutions provide hydrolysis of the cell wall fraction where fraction B3 is fixed. However, in this study only the addition of urea, regardless of the moisture content, was shown to be efficient in reducing this fraction compared with the other materials.

In fraction $\mathrm{C}$, which represents the percentage of the total nitrogen that is insoluble, higher values were observed for the untreated hay compared to those treated with the addition of urea or ammonia. Contradictory effects are reported in the literature with respect to the effects of ammoniation on this parameter. Rosa et al. (1998) reported increases in the

Table 2 - Nitrogen fractions of Brachiaria brizantha treated with urea or anhydrous ammonia $\left(\mathrm{NH}_{3}\right)$ with different moisture contents and the untreated control

\begin{tabular}{|c|c|c|c|c|c|}
\hline \multirow[t]{2}{*}{ Item } & $\mathrm{A}^{1}$ & B1 & B2 & B3 & $\mathrm{C}$ \\
\hline & \multicolumn{5}{|c|}{$\%$ Total nitrogen } \\
\hline Untreated hay with $15 \%$ moisture & 19.9d & $27.3 \mathrm{a}$ & $25.1 \mathrm{a}$ & $4.5 \mathrm{a}$ & $23.2 \mathrm{a}$ \\
\hline Hay 25\% moisture with 3\% urea & 69.1bc & $2.0 \mathrm{~b}$ & $11.9 \mathrm{bc}$ & $1.3 c$ & $15.8 \mathrm{bc}$ \\
\hline Hay $30 \%$ moisture with $3 \%$ urea & $64.4 \mathrm{c}$ & $3.4 \mathrm{~b}$ & $14.3 \mathrm{~b}$ & $1.3 \mathrm{c}$ & $16.7 b$ \\
\hline Hay $25 \%$ moisture with $5 \%$ urea & $73.5 \mathrm{ab}$ & $3.8 \mathrm{~b}$ & $9.8 \mathrm{bc}$ & $1.0 \mathrm{c}$ & $11.9 \mathrm{~cd}$ \\
\hline Hay 30\% moisture with 5\% urea & $77.1 \mathrm{a}$ & $7.2 b$ & $6.2 \mathrm{c}$ & $1.6 \mathrm{bc}$ & 7.9d \\
\hline Hay $15 \%$ moisture with $3 \%$ ammonia & $71.2 b$ & $5.9 \mathrm{~b}$ & $10.3 \mathrm{bc}$ & 3.0abc & $9.6 \mathrm{~d}$ \\
\hline Hay $25 \%$ moisture with $3 \%$ ammonia & $70.7 \mathrm{~b}$ & $6.3 b$ & $9.1 \mathrm{bc}$ & 3.8ab & $10.1 \mathrm{~d}$ \\
\hline Hay $30 \%$ moisture with $3 \%$ ammonia & 73.6ab & $2.7 b$ & $9.7 \mathrm{bc}$ & $4.6 \mathrm{a}$ & $9.4 \mathrm{~d}$ \\
\hline Average & 64.9 & 7.3 & 12.0 & 2.6 & 13.1 \\
\hline CV (\%) & 3.6 & 45.6 & 25.6 & 37.7 & 13.4 \\
\hline
\end{tabular}

Averages followed by different letters in the columns differ $(\mathrm{P}<0.05)$ by the Tukey test

${ }^{1} \mathrm{~A}$ : soluble fraction, or non-protein nitrogen; B1: fraction rapidly degraded in the rumen; B2: insoluble fraction, with an intermediate rate of degradation in the rumen; B3: insoluble fraction slowly degraded in the rumen; and C: insoluble fraction in the rumen and indigestible in the gastrointestinal tract expressed in total nitrogen percentage. 
acid detergent insoluble nitrogen contents (ADIN) in the hay, while Reis et al. (1993), Fernandes et al. (2002) and Reis et al. (2003) did not observe significant alterations in this fraction. To make a joint analysis between Tables 1 and 2 , relating the ADIN (Table 1 ) and the fraction C contents (Table 2), it should be remembered that the quantity of the fixed insoluble nitrogen in the fiber fraction increases (ADIN), but due to the inclusion of the nitrogen contribution, especially in the soluble fraction (A), the fraction $C$ value decreases, which can be considered a beneficial effect, since this is a fraction that is unavailable to ruminal degradation.

Fractions A and B1 refer to the concentration of soluble sugars with rapid ruminal degradation and starch, fructosans, galactans, $\beta$-glucans and pectin, with intermediate degradation, respectively. It was observed that hay treated with 5\% urea at a 30\% moisture content presented a lower value in fractions A and B1 (7.6\%), showing significant differences only with the control hay, the hay treated with 3\% urea and 25 and 30\% moisture, with values of $11.4,12$ and $11.3 \%$, respectively (Table 3 ). Thus, there were very low contents of these fractions in all the hay samples, and this was probably due to the absence of starch and the reduced amount of soluble sugars in the hay from Brachiaria brizantha cv. Marandu, treated or untreated.

The values of fraction B2 (Table 3) are more representative, and they were consistent with the studied materials. This value represents the fraction corresponding to the potentially digestible fiber - the polysaccharides that compose the cell wall, such as cellulose and hemicellulose. In the hay that had 3 and 5\% urea added at 30\% moisture

Table 3 - Carbohydrate fractions from the Brachiaria brizantha cv. Marandu hay, treated or untreated with urea, with anhydrous ammonia $\left(\mathrm{NH}_{3}\right)$ in different moisture contents

\begin{tabular}{lccc}
\hline Item & $\mathrm{A}+\mathrm{B} 1^{1}$ & $\mathrm{~B} 2$ & $\mathrm{C}$ \\
\cline { 2 - 4 } & $\%$ of & total carbohydrates \\
\hline Untreated hay with 15\% moisture & $11.4 \mathrm{a}$ & $52.7 \mathrm{ab}$ & 35.9 \\
Hay 25\% moisture with 3\% urea & $12.0 \mathrm{a}$ & $52.1 \mathrm{~b}$ & 35.9 \\
Hay 30\% moisture with 3\% urea & $11.3 \mathrm{a}$ & $57.6 \mathrm{a}$ & 31.1 \\
Hay 25\% moisture with 5\% urea & $10.7 \mathrm{ab}$ & $53.8 \mathrm{ab}$ & 35.4 \\
Hay 30\% moisture with 5\% urea & $7.6 \mathrm{~b}$ & $57.6 \mathrm{a}$ & 34.8 \\
Hay 15\% moisture with 3\% ammonia & $9.2 \mathrm{ab}$ & $57.2 \mathrm{ab}$ & 33.6 \\
Hay 25\% moisture with 3\% ammonia & $10.8 \mathrm{ab}$ & $55.6 \mathrm{ab}$ & 33.6 \\
Hay 30\% moisture with 3\% ammonia & $9.5 \mathrm{ab}$ & $56.2 \mathrm{ab}$ & 34.3 \\
Average & 10.3 & 55.4 & 34.3 \\
CV (\%) & 14.4 & 4.2 & 7.2 \\
\hline
\end{tabular}

Averages followed by different letters in the columns differ $(\mathrm{P}<0.05)$ by Tukey test.

${ }^{1}$ A: rapidly degraded fraction; B1: intermediately degraded fraction; B2: slowly degraded fraction and $\mathrm{C}$ : indigestible fraction, expressed in percentage of total carbohydrates. content, the values of these fractions were $57.6 \%$ in both roughages, and were significantly higher when compared with the hay treated with 3\% urea and 25\% moisture (52.1\%).

The fraction $C$ values, which represent the indigestibility, did not differ significantly and showed no difference between the urea or ammonia treatments compared to the control hay.

In relation to the carbohydrate fiber content (Table 4), the untreated hay showed the highest contents of neutral detergent fiber (NDF) (84.3\%), but this was not statistically different from the hay treated with $3 \%$ urea, regardless of the moisture content. On the other hand, the hay samples that had the greatest reductions in the NDF content were those treated with anhydrous ammonia at 25 and 30\% moisture, with values of $77.1 \%$ and $76.6 \%$, respectively. Nevertheless, these did not differ from the hay treated with $5 \%$ urea, regardless of the moisture content, and those treated with 3\% ammonia with 15\% moisture.

In some studies (Reis et al., 1995, Pereira et al., 1993), one of the main modifications in the chemical composition of the fiber fraction of ammoniated roughage was the decrease in the neutral detergent fiber content.

Fernandes et al. (2002) obtained a reduction of 4.47 percentage points with the addition of $3 \%$ ammonia to Brachiaria decumbens hay and explained these results as the solubilization of part of the hemicellulose. In our study, the greatest difference was obtained in the hay treatment with 3\% ammonia and 30\% moisture, which accounted for 15.1 percentage points in relation to the control hay. The hay with the addition of ammonia and the lowest moisture content, as well as the hay treated with 5\% urea, showed more modest reductions of around 7 percentage points.

There were no observed significant differences between treatments for acid detergent fiber (ADF) (Table 4). In most studies reviewed regarding hay ammoniation, there were no changes in the ADF content (Reis \& Rodrigues, 1994), corroborating the results obtained in the present experiment.

The hemicellulose contents was statistically different among the treatments; however, the untreated hay did not differ from any of the treatments, as it presented intermediate values. According to Reis et al. (1990), one of the main alterations in the chemical composition of the fiber fraction of the roughage that is treated with ammonia or urea is hemicellulose solubilization, resulting in decreased neutral detergent fiber content. However, in the present study, this reduction was not significant, nevertheless, the expected result of a reduction in neutral detergent fiber occurred. These results may be associated 
with the ammonolysis reactions, ammonium hydroxide formation and lignin alkaline hydrolysis, which are more striking compared to reactions with the hemicellulose chains.

The ammoniation with urea promoted a decrease $(\mathrm{P}<0.05)$ in the lignin content of the hay. Nevertheless, there was no difference between the treatments treated with $\mathrm{NH}_{3}$ or urea (Table 4). In the literature, there is a great contradiction in the results of ammoniation on lignin content. Some authors have demonstrated a decrease in the content (Queiroz et al., 1992). Rosa et al. (1998) observed a $24.6 \%$ decrease in the lignin content in response to adding urea to the hay. According to Van Soest (1994), lignin solubilization may occur with a sharp increase in $\mathrm{pH}$ but without affecting the cellulose content.

The hay that showed lower lignin contents compared to the control hay (13.1\%) were those with 3\% ammonia with $25 \%$ and $30 \%$ moisture and the treatment with $3 \%$ urea with $30 \%$ moisture, which were $10.9,10.8$ and $11 \%$, respectively.

The highest values of the dry matter in vitro digestibility (IVDDM) were observed in the hay with 3\% $\mathrm{NH}_{3}, 25 \%$ and $30 \%$ moisture, and did not differ from the treatment with the same dose of $\mathrm{NH}_{3}$ with $15 \%$ moisture $(\mathrm{P}>0.05)$. In relation to the hay treated with urea, statistical similarity was only seen in the hay that had a lower IVDDM compared to those treated with $\mathrm{NH}_{3}(55.5 \%)$ - this was the hay that had $5 \%$ urea and $30 \%$ moisture (49.4\%). The other hay treated with urea did not differ $(\mathrm{P}>0.05)$ from the control hay (Table 4).
The digestibility contents can be significantly increased as a result of the ammoniation process through the interference of the reductions in neutral detergent fiber, lignin and an increase in CP contents. According to Fernandes et al (2002), the observed increase in digestibility was probably due to changes in the chemical composition of the fiber fraction, with a decrease in the neutral detergent fiber content that provided a greater amount of readily digestible carbohydrates to the rumen microorganisms. Associated with these modifications, the increase in available nitrogen gave better conditions for ruminal bacteria development that also increased the forage digestibility.

These authors obtained an increase of 12.1 and 6.6 percentage points in the dry matter in vitro digestibility values of hay treated with ammonia and urea, respectively. In this experiment, an increase of 20.7 percentage points was observed between the control hay and the hay treated with $3 \%$ ammonia at 30\% moisture content, with a more moderate increase in treatments with urea of about 5 percentage points.

It can be confirmed that the treatment of hay with anhydrous ammonia reduced the amount of neutral detergent fiber and promote a significant increase in the digestibility compared to the control group, but the variation in moisture content did not significantly alter the action of ammonia. Regarding the treatment with urea, the 5\% dose was the only one that resulted in differences in the neutral detergent fiber compared to the untreated hay, but to have an effect on digestibility, it was necessary to increase the moisture content to $30 \%$.

Table 4 - Fiber carbohydrate content, lignin and digestibility of hay from Brachiaria brizantha cv. Marandu, treated with urea and anhydrous ammonia $\left(\mathrm{NH}_{3}\right)$ and different moisture contents

\begin{tabular}{|c|c|c|c|c|c|c|}
\hline \multirow[t]{2}{*}{ Item } & $\mathrm{NDF}^{1}$ & $\mathrm{ADF}$ & Hemicellulose & Cellulose & Lignin & IVDDM \\
\hline & \multicolumn{6}{|c|}{$\% \mathrm{DM}$} \\
\hline Untreated hay with $15 \%$ moisture & $84.3 a$ & 64.7 & 19.6ab & 51.6 & $13.1 \mathrm{a}$ & $37.3 d$ \\
\hline Hay 25\% moisture with 3\% urea & $81.1 \mathrm{ab}$ & 61.3 & $19.8 \mathrm{a}$ & 48.8 & $12.5 \mathrm{ab}$ & $40.2 d$ \\
\hline Hay $30 \%$ moisture with $3 \%$ urea & $82.0 \mathrm{ab}$ & 64.2 & $17.7 \mathrm{ab}$ & 53.2 & $11.0 \mathrm{~b}$ & $42.6 \mathrm{~cd}$ \\
\hline Hay $25 \%$ moisture with $5 \%$ urea & 79.7bc & 61.7 & $18.0 \mathrm{ab}$ & 49.7 & $12.0 \mathrm{ab}$ & $37.4 \mathrm{~d}$ \\
\hline Hay 30\% moisture with 5\% urea & $79.6 \mathrm{bc}$ & 60.7 & 18.9ab & 49.6 & $11.1 \mathrm{ab}$ & 49.4bc \\
\hline Hay $15 \%$ moisture with $3 \%$ ammonia & 79.1bc & 62.5 & $16.6 b$ & 51.4 & $11.1 \mathrm{ab}$ & $55.5 \mathrm{ab}$ \\
\hline Hay $25 \%$ moisture with $3 \%$ ammonia & $77.1 \mathrm{c}$ & 59.9 & $17.2 \mathrm{ab}$ & 49.0 & $10.9 b$ & $58.3 a$ \\
\hline Hay $30 \%$ moisture with $3 \%$ ammonia & $76.6 \mathrm{c}$ & 59.7 & 16.9ab & 48.9 & $10.8 \mathrm{~b}$ & $58.0 \mathrm{a}$ \\
\hline Average & 79.9 & 61.9 & 18.1 & 50.3 & 11.5 & 47.3 \\
\hline CV (\%) & 1.8 & 3.4 & 7.2 & 4.3 & 7.5 & 6.3 \\
\hline
\end{tabular}

Averages followed by different letters in the columns differ $(\mathrm{P}<0.05)$ by Tukey test.

${ }^{1}$ NDF: neutral detergent fiber; ADF: acid detergent fiber; IVDDM: in vitro digestibility of dry matter, expressed in $\%$ DM.

\section{Conclusions}

Ammonia can be applied with the original moisture content of the hay and urea should be used at a dose of $5 \%$ on the dry matter with $30 \%$ moisture.

\section{References}

ASSOCIATION OF OFFICIAL ANALYTICAL CHEMISTS - AOAC. Official methods of analysis. 15.ed. Washington: AOAC, 1990. $1298 p$.

BERCHIELli, T.T.; ANDRADE, P.; FURLAN, C.L. Avaliação de 
indicadores internos em ensaios de digestibilidade. Revista Brasileira de Zootecnia, v.29, n.3, p.830-833. 2000 (supl.). BERGER, L.L.; FAHEY JR., G.C.; BOURQUIN, L.D. et al. Modification of forage quality after harvest. In: FAHEY JR., G.C.; COLLINS, M.; MERTENS, D.R. (Eds.). Forage quality evaluation, and utilization. Madison: American Society of Agronomy: Crop Science Society of America, 1994. p.922-966.

BUETTNER, M.R.; LECHTENBERG, V.L.; HENDRIX, K.S. et al. Composition and digestion of ammoniated tall fescue (Festuca arundinacea Schreb.) hay. Journal of Animal Science, v.54, n.1, p.173-178, 1982.

DOLBERG, D.F. Progress in the utilization of urea ammonia treated crop residues: Nutritional dimensions and applications of the technology on small farms. In: SIMPÓSIO INTERNACIONAL DE RUMINANTES, 28., 1991, Lavras. Anais... Lavras: Sociedade Brasileira de Zootecnia, 1991. p.130-140.

FENNER, H. Method for determining total volatile bases in rumen fluid by steam distillation. Journal of Dairy Science, v.48, n.2, p.249-251, 1965.

FERNANDES, L.O.; REIS, R.A.; RODRIGUES, L.R.A. et al. Qualidade de feno de Brachiaria decumbens Stapf. submetido ao tratamento com amônia anidra ou ureia. Revista Brasileira de Zootecnia, v.31, n.3, p.1325-1332, 2002 (supl.).

FREITAS, D.; COAN, R.M.; REIS, R.A. et al. Avaliação de fontes de amônia para conservação do feno de alfafa (Mendicago sativa L.) armazenado com alta umidade. Revista Brasileira de Zootecnia, v.31, n.2, p.866-874, 2002 (supl.).

JOY, M., ALIBÉS, X.; MUÑOZ, F. Chemical treatment of lignocellulosic residues with urea. Animal Feed Science and Technology, v.38, n.3-4, p.319-333, 1992.

LICITRA, G.; HERNANDEZ, T.M.; VAN SOEST, P.J. Standardization of procedures for nitrogen fractionation of ruminant feeds. Animal Feed Science and Technology, v.57, n.2, p.347-358, 1996.

MASCARENHAS-FERREIRA, A.; GUEDES, C.V.M.; DIAS-DASILVA, A.A. Effect of urea treatment on chemical composition and in vitro digestibility of meadow hays of Northern Portugal. Animal Feed Science and Technology, v.25, n.1, p.157-167, 1989.

PEREIRA, J.R.A.; EZEQUIEL, J.M.B.; REIS, R.A. et al. Efeitos da amonização sobre o valor nutritivo do feno de capim braquiária. Pesquisa Agropecuária Brasileira, v.28, n.12, p.1451-1455, 1993.

PIRES, A.J.V.; REIS, R.A.; SIQUEIRA, G.R. et al. Composição química do feno de Brachiaria brizantha amonizado em diferentes umidades. Archivos de Zootecnia, v,55, n.212, p.393-396, 2006.

QUEIROZ, A.C.; LEMENAGER, R.P.; HENDRIX, K.S. et al. Efeito do tratamento da palha de trigo com amônia anidra sobre a proteína bruta, digestibilidade in vitro da matéria seca e os componentes da fibra, após vários tempos de amonização e período de aeração. Revista Brasileira de Zootecnia, v.21, n.6, p.1020-1028, 1992 .

REIS, R.A.; GARCIA, R.; QUEIROZ, A.C. et al. Efeitos da aplicação de amônia anidra sobre a digestibilidade do feno do capim- braquiária (Brachiaria decumbens Stapf). Revista Brasileira de Zootecnia, v.19, n.3, p.201-208, 1990.

REIS, R.A.; GARCIA, R.; QUEIROZ, A.C. et al. Efeitos da amonização sobre a qualidade dos fenos de gramíneas tropicais. Pesquisa Agropecuária Brasileira, v.26, n.8, p.1183-1191, 1991.

REIS, R.A.; RODRIGUES, L.R.A.; NAHAS, H. et al. Amonização do feno de Brachiaria decumbens com diferentes teores de umidade. Pesquisa Agropecuária Brasileira, v.28, n.4, p.539-543, 1993.

REIS, R.A.; RODRIGUES, L.R.A. Amonização de volumosos. 1.ed. Jaboticabal: FUNEP, 1993. 22p.

REIS, R.A.; RODRIGUES, L.R.A. Amonização de forrageiras de baixa qualidade. In: SIMPÓSIO BRASILEIRO DE FORRAGEIRAS E PASTAGENS, 1., 1994, Campinas. Anais... Campinas: Colégio Brasileiro de Nutrição Animal, 1994. p.89-105.

REIS, R.A.; ANDRADE, P.; RODRIGUES, L.R.A. et al. Palha de arroz e feno de Brachiaria brizantha amonizados e suplementados com energia ou proteína na alimentação de bovinos. Revista Brasileira de Zootecnia, v.24, n.5, p.832-840, 1995.

REIS, R.A.; RODRIGUES, L.R.A.; PEREIRA, J.R.A. et al. Composição química e digestibilidade de fenos tratados com amônia anidra ou ureia Revista Brasileira de Zootecnia, v.30, n.3, p. 666-673, 2001.

REIS, R.A.; BERCHIELI, T.T.; ANDRADE, P. et al. Valor nutritivo do feno de capim coast-cross (Cynodon dactylon L. Pers) submetido a amonização. Ars. Veterinária, v.19, n.2, p.143-149, 2003.

ROSA, B.; REIS, R.A.; RESENDE, K.T. et al. Valor nutritivo dos fenos de Brachiaria decumbens Stapf cv. Basilisk submetido a tratamento com amônia anidra ou ureia. Revista Brasileira de Zootecnia, v. 27, n. 4, p. 815-822. 1998.

SAHNOUNE, S.; BESLE, J.M.; CHENOST, M. et al. Treatment of straw with urea. 1. Ureolysis in a low water medium. Animal Feed Science and Technology, v.34, n.12, p.75-93, 1991.

STATISTICAL ANALYSIS SYSTEM - SAS. The SAS system for Windows: version: 8.2. Cary: SAS Institute, 1999. (CD-ROM).

SILVA, D.J.; QUEIROZ, A.C. Análise de alimentos: métodos químicos e biológicos. 3.ed. Viçosa, MG: Universidade Federal de Viçosa, 2002. 235p.

SNIFFEN, C.J.; O'CONNOR, J.D.; VAN SOEST, P.J. et al. A net carbohydrate and protein system for evaluating cattle diet. II. Carbohydrate and protein availability. Journal of Animal Science, v.70, n.12, p.3562-3577, 1992.

SOUZA, F.H.D.; SILVEIRA, G.C. A palhada residual da produção de sementes de capins tropicais no Brasil. In: SOUZA, F.H.D.; POTT, E.B.; PRIMAVESI, O. et al. (Eds). Usos alternativos da palhada residual da produção de sementes para pastagens. São Carlos: EMBRAPA, 2006. p.13-28.

SUNDSTOL, F.; COXWORTH, E.M. Ammonia treatment. In: SUNDSTOL, F.; OWEN, E. (Eds.) Straw and others fibrous byproducts as feed. Amsterdam: Elsevier Press, 1984, p.196-247.

VAN SOEST, P. Nutricional ecology of the ruminant 2.ed. Ithaca: Cornell University Press, 1994. 476p.

VIEIRA, P.F. Efeito do formaldeído na proteção de proteínas e lipídeos em rações para ruminantes. 1980. 98f. Tese (Doutorado em Zootecnia) - Universidade Federal de Viçosa, Viçosa, MG. 